\title{
Article \\ Tribology and Airborne Particle Emission of Laser-Cladded Fe-Based Coatings versus Non-Asbestos Organic and Low-Metallic Brake Materials
}

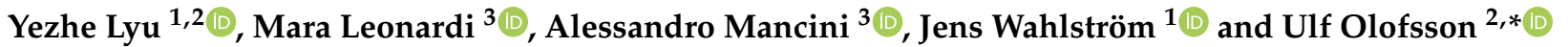 \\ 1 Department of Mechanical Engineering Sciences, Lund University, SE-22100 Lund, Sweden; \\ yezhe.lyu@mel.lth.se (Y.L.); jens.wahlstrom@mel.lth.se (J.W.) \\ 2 Department of Machine Design, KTH Royal Institute of Technology, SE-10044 Stockholm, Sweden \\ 3 Advanced R\&D Department, Brembo S.p.A, 24040 Stezzano, BG, Italy; Mara_Leonardi@brembo.it (M.L.); \\ Alessandro_Mancini@brembo.it (A.M.) \\ * Correspondence: ulfo@md.kth.se; Tel.: +46-(0)-8-790-6304
}

\section{check for} updates

Citation: Lyu, Y.; Leonardi, M.; Mancini, A.; Wahlström, J.; Olofsson, U. Tribology and Airborne Particle Emission of Laser-Cladded Fe-Based Coatings versus

Non-Asbestos Organic and Low-Metallic Brake Materials. Metals 2021, 11, 1703. https://doi.org/ $10.3390 /$ met11111703

Academic Editor: Andre

Paulo Tschiptschin

Received: 27 September 2021

Accepted: 23 October 2021

Published: 26 October 2021

Publisher's Note: MDPI stays neutral with regard to jurisdictional claims in published maps and institutional affiliations.

Copyright: (c) 2021 by the authors. Licensee MDPI, Basel, Switzerland. This article is an open access article distributed under the terms and conditions of the Creative Commons Attribution (CC BY) license (https:/ / creativecommons.org/licenses/by/ $4.0 /)$.

\begin{abstract}
Laser cladding is a promising surface treatment for refurbishing worn-out cast-iron brake rotors. Previous studies on laser-cladded brake rotors have demonstrated their extensively higher wear and greater airborne particle emissions, compared with traditional cast iron rotors. In order to overcome this, a commercial non-asbestos organic (NAO) brake material is tested against Fe-based laser-cladded and traditional cast-iron brake rotors. Two low-metallic brake pad materials are also tested as references. The materials' coefficients of friction, specific wear rates and particle number concentrations are evaluated. The results indicate that the NAO brake material showed lower wear and had fewer particle emissions than the low-metallic brake materials when deployed against both cast iron and laser-cladded brake rotors. The NAO/laser-cladding friction pairing showed wear, particle concentration and fraction of fine particles (sub $1 \mu \mathrm{m}$ ) equivalent to those of the low-metallic/cast-iron friction pairing, creating significant potential for application in refurbishing worn-out cast-iron brake rotors.
\end{abstract}

Keywords: laser cladding; airborne particle emission; non-asbestos organic; low-metallic brake pad

\section{Introduction}

A brake rotor is a crucial component in an automotive disc-brake system that slows a vehicle by friction with its brake pads. For decades, grey cast iron (GCI) has been the most popularly used material for brake rotors, owing to its excellent castability, high thermal conductivity, good damping capability and cost-effectiveness. However, GCI is not satisfying in terms of corrosion resistance, wear resistance or airborne particle emission [1]. Different attempts have been made to combat these deficiencies. One such strategy is the application of alternative materials to replace GCI in producing automotive brake rotors. Such alternative materials include metal matrix composites [2] and ceramic matrix composites [3], but these materials are more expensive than GCI, and, thus, are not suitable for commercial use in automotive brake rotors. Another strategy is to overlay a protective coating on the GCI substrate. This method is encouraging, since it is not only suitable for producing brand-new brake rotors, but also capable of refurbishing worn brake rotors.

Aranke et al. carried out a thorough literature review on coating technologies and materials for GCI brake rotors [1]. Depending on their working temperatures, coating technologies can be categorized by non-thermal spray processes and thermal spray processes. One of the thermal spray processes, HVOF (high-velocity oxy-fuel), has been shown to capably produce wear-resistant cermet coatings on GCI brake discs with reduced airborne particle emission [4-7]; the main disadvantages of HVOF are found in its very costly equipment and restrictive powder sizes (usually below $50 \mu \mathrm{m}$ ) [8]. 
Laser cladding is a representative non-thermal spray process with strong metallurgical bonding and a small heat-affected zone between the substrate and coating, upon the latter of which hardfacing materials can be deposited for use in applications such as GCI brake discs. Laser-cladded Ni-based and Co-based coatings, reinforced with tungsten carbides, have demonstrated superior wear resistance and lesser airborne particle emissions than nude GCI brake discs [9-13]. However, Ni, Co, W and their compounds are widely recognized to cause a series of hazards to human health, such as cardiovascular deficits, skin allergies and lung fibrosis [14-16]; and this, notwithstanding the dramatic increase in their prices over the last decades [17]. Accordingly, explorations of other less-toxic alternatives for the application of laser cladding to GCI brake disc are needed. In a recent work on HVOF, Fe-based coatings, sprayed onto a GCI substrate, showed tribological performance that was comparable with Ni/Co-based coatings [18-21], whilst relevant knowledge on lasercladding-sprayed Fe-based coatings is very scarce. A recent life-cycle assessment, in terms of energy consumption and carbon footprint, suggested the great potential of laser-cladded Fe-based coatings in refurbishing worn-out GCI brake discs [22]. The study also presented the greater wear and emission of airborne particles of laser-cladded Fe-based coatings than of uncoated GCI brake discs. This is probably attributed to the tribological compatibility of metals [23] in sliding contact, since both the laser-cladded rotor surface, as well as the pad material, contained large amounts of Fe. A semi-metallic brake pad can contain between $10-30 \%$ Fe. Here, the term compatibility means a reluctance to form a strong interfacial bond, which leads to a high wear rate; better tribological compatibility can be achieved using, for instance, Ti compounds, as a replacement for Fe [23]. This is the case for non-asbestos organic (NAO) brake pads, which often contain around 1\% Fe and use Ti compounds as an Fe replacement. Therefore, there is a demand for further research on laser-cladded Fe-based coatings, regarding the selection of suitable brake-pad and coating materials with moderate CoFs and reduced wear and particle emissions. The current study aims to evaluate the friction, wear and airborne particle emissions of a laser-cladded Fe-based coating on GCI brake discs tested against a non-asbestos organic (NAO) and two semi-metallic (a Cu-containing and a Cu-free) brake-pad materials.

\section{Experimental Set-Up}

\subsection{Pin-on-Disc Tribometer}

The tests were carried out using a pin-on-disc (PoD) tribometer, dedicated to airborne particle-emission measurement, as sketched in Figure 1. The PoD tribometer was comprised of a horizontally rotational disc and a vertically dead-loaded pin. By adjusting the dead weight and rotational speed of the motor, desired pin/disc contact pressures and sliding speeds can be achieved. An HBM $^{\circledR}$ (Darmstadt, Germany) Z6FC3/20-kg-load cell was mounted on the side of the pin-holder that measured the tangential force at the pin-disc contact. The coefficient of friction $(\mathrm{CoF})$ between the pin and disc was indirectly calculated by dividing the measured tangential force by the normal load. The PoD tribometer was placed in a one-way ventilated box with an inlet and an outlet. Room air was pumped through a HEPA filter (class H13 EN 1822) to eliminate background particles, ensuring a particle-free air inlet. A TSI ${ }^{\circledR}$ (Shoreview, MN, USA) model-8455 air-velocity transducer was mounted at the inlet to measure air velocity, facilitating the control of stable air flow in the test box. Due to the complexity of the PoD tribometer, the air pumped into the box mixed well with the generated particles and transported the particles to the air outlet. At the air outlet, a TSI ${ }^{\circledR}$ optical particle sizer, model 3330 (OPS), was used to measure particle number concentrations (PNCs) for particles with diameters between $0.3 \mu \mathrm{m}$ and $10 \mu \mathrm{m}$, at $1 \mathrm{~Hz}$. Due to the fact that the OPS is sensitive to the forms and refractive indices of particles, the measured particle-size distributions and number concentrations should be considered approximate [24]. Therefore, the output from the OPS was only used as a relative measure when ranking different material combinations. 


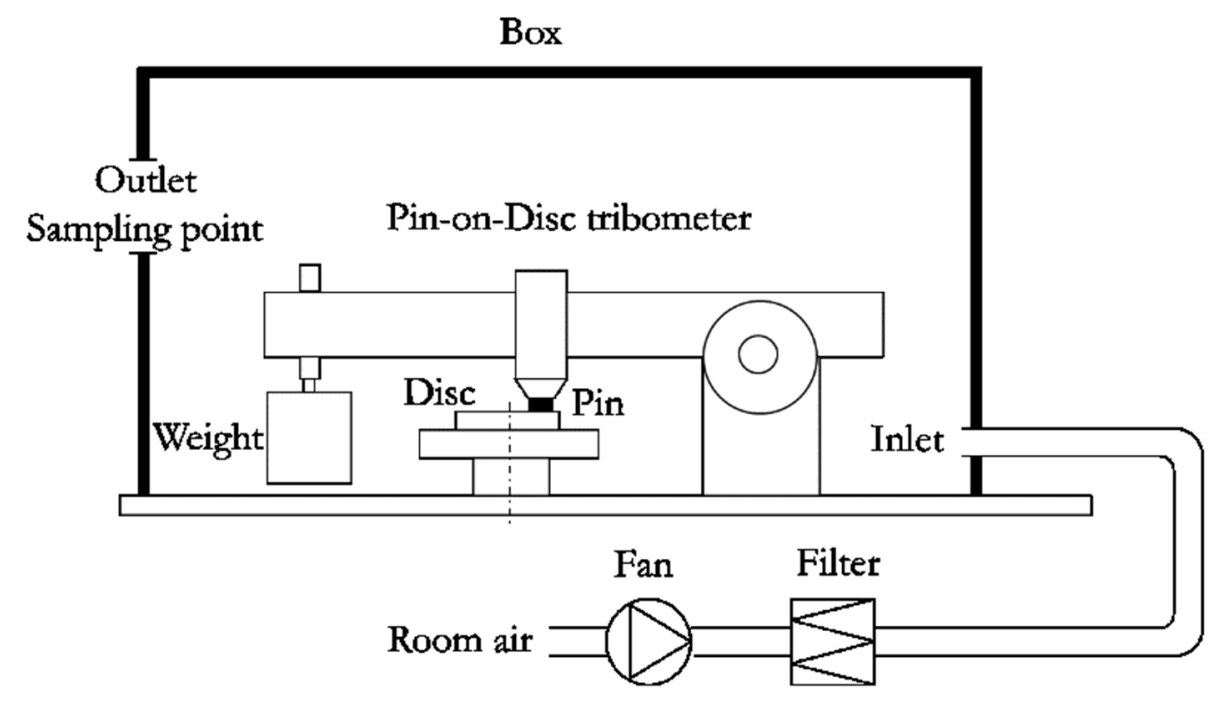

Figure 1. Schematic of the pin-on-disc setup [25].

\subsection{Materials}

In the current study, two brake disc materials, i.e., a commercial GCI and a lasercladding-sprayed Fe-based coating were tested against three commercial brake pad materials (an NAO and two low-metallic materials). The Fe-based coatings were laser-cladded onto the reference GCI disc and this was conducted with a 7-kW fibre-coupled diode laser (Laserline ${ }^{\circledR}$ (Bristol, UK) LDF 7000-40), featuring a beam quality of $40 \mathrm{~mm} . \mathrm{mrad}$ and fibre-optic cables $400 \mu \mathrm{m}$ in diameter. A Fraunhofer ILT $^{\circledR}$ (Hague, The Netherlands) three-jet nozzle was used to inject the metal powder into its destination, allowing a possible track width of 1.0-6.0 mm. In order to minimize the heat input into the disc substrate, the parameters shown in Table 1 were used to laser-clad the Fe-based coatings.

Table 1. Laser-cladding and powder parameters of the Fe-base coating.

\begin{tabular}{cc}
\hline Parameter & Value \\
\hline laser spot size & $\varphi 2 \mathrm{~mm}$ \\
laser power & $950 \mathrm{~W}$ \\
weld beam overlaps & $50 \%$ \\
laser head travel speed & $8 \mathrm{~mm} / \mathrm{s}$ \\
metal powder feed rate & $7 \mathrm{~g} / \mathrm{min}$ \\
metal powder diameter & $53-150 \mu \mathrm{m}$ \\
\hline
\end{tabular}

The GCI and Fe-based powder metal, as well as the three brake pad materials, are all commercial products and their chemical compositions are either listed by the manufacturer or were obtained with XRF (X-ray fluorescence spectrometer), as shown in Table 2. In order to fit the brake pad and disc materials into the dedicated PoD tribometer, the three brake pad materials were cut into cylindrical pin samples with $10-\mathrm{mm}$ diameter testing surfaces, and the two brake disc materials were manufactured into round disc samples of $100-\mathrm{mm}$ diameter and 8-mm thickness.

\subsection{Test Conditions}

The test conditions for varied pin/disc combinations were obtained in a series of pretests to reach an identical friction force between the brake pad and disc that corresponded to the measured tangential force in the current study. The reason for such a test design was to simulate the conditions of driving, in practice. In reality, drivers tend to dynamically adjust the load on the brake pedal to reach a desired friction force between the pad and disc, in such a way as to stop the car with a certain deceleration and within a certain braking distance. If the friction force is too low, a higher load will be applied to compensate. Due 
to the different CoFs obtained in the pre-tests, test conditions were varied for the pin/disc combinations and are listed in Table 3. Each pin/disc combination was repeated four times in order to obtain their mean values and standard deviations of $\mathrm{CoF}$, wear rate and PNC.

Table 2. Chemical compositions and surface conditions of the brake-disc and -pad materials.

\begin{tabular}{|c|c|c|c|c|c|}
\hline Element wt.\% & GCI Disc & Laser-Cladded Disc & NAO Pin & $\begin{array}{c}\text { Low-Metallic } \\
\text { Pin/Cu-Contained }\end{array}$ & $\begin{array}{c}\text { Low-Metallic } \\
\text { Pin/Cu-Free }\end{array}$ \\
\hline $\mathrm{Al}$ & - & - & 1.6 & 5.8 & 8.1 \\
\hline $\mathrm{Ba}$ & - & - & 4.7 & - & - \\
\hline $\mathrm{C}$ & 3.8 & 0.15 & $\mathrm{~N} / \mathrm{A}$ & $\mathrm{N} / \mathrm{A}$ & $\mathrm{N} / \mathrm{A}$ \\
\hline $\mathrm{Ca}$ & - & - & 8.0 & 3.5 & 1.2 \\
\hline $\mathrm{Cr}$ & - & 18 & - & 1.5 & 3.0 \\
\hline $\mathrm{Cu}$ & - & - & - & 12.3 & $\mathrm{~N} / \mathrm{A}$ \\
\hline $\mathrm{Fe}$ & Balance & Balance & 1.2 & 13.1 & 26.0 \\
\hline $\mathrm{Mg}$ & - & - & 9.2 & 8.2 & 12.2 \\
\hline $\mathrm{Mn}$ & 0.65 & - & - & - & - \\
\hline Mo & & 0.5 & - & - & - \\
\hline $\mathrm{Ni}$ & - & 2.5 & - & - & - \\
\hline $\mathrm{P}$ & 0.06 & - & - & 0.6 & $\mathrm{~N} / \mathrm{A}$ \\
\hline$S$ & 0.05 & - & 4.1 & 4.0 & 3.9 \\
\hline $\mathrm{Si}$ & 1.8 & - & 5.2 & 3.7 & 1.4 \\
\hline Sn & - & - & 8.1 & 6.7 & 6.6 \\
\hline $\mathrm{Ti}$ & - & - & 16.3 & - & - \\
\hline $\mathrm{Zn}$ & - & - & 1.1 & 8.7 & 1.4 \\
\hline $\mathrm{Zr}$ & - & - & 32.6 & - & - \\
\hline Others & - & - & Balance & Balance & Balance \\
\hline Hardness (HRC) & 20 & 58 & $\mathrm{~N} / \mathrm{A}$ & $\mathrm{N} / \mathrm{A}$ & $\mathrm{N} / \mathrm{A}$ \\
\hline Density $\left(\mathrm{g} / \mathrm{cm}^{3}\right)$ & 7.1 & 13.58 & 2.23 & 2.76 & 2.74 \\
\hline $\begin{array}{c}\text { Average initial } \\
\text { surface roughness }\end{array}$ & $\mathrm{Ra}=0.30 \mu \mathrm{m}$ & $\mathrm{Ra}=0.25 \mu \mathrm{m}$ & Scorched & Scorched & Scorched \\
\hline Code name & GCI & $\mathrm{LC}$ & $\mathrm{NAO}$ & Cu-contained & Cu-free \\
\hline
\end{tabular}

Table 3. Contact pressure and sliding speed for different material combinations.

\begin{tabular}{ccccc}
\hline Disc & Pin & Contact Pressure & Sliding Speed & Test Duration \\
\cline { 2 - 3 } LC & NAO & $0.35 \mathrm{MPa}$ & & \\
\cline { 2 - 3 } & $\begin{array}{c}\text { Cu-containing } \\
\text { Cu-free }\end{array}$ & $0.45 \mathrm{MPa}$ & $2 \mathrm{~m} / \mathrm{s}$ & $2 \mathrm{~h}$ \\
GCI & $\begin{array}{c}\text { NAO } \\
\text { Cu-containing } \\
\text { Cu-free }\end{array}$ & $0.6 \mathrm{MPa}$ & & \\
\hline
\end{tabular}

\subsection{Characterization of Worn Samples}

The worn surfaces of the pins and discs were observed with a scanning electron microscope (SEM) equipped with an energy dispersive X-ray spectroscope (EDXS). In detail, the analysis was conducted with a Zeiss MA EVO10 microscope, equipped with a $10-\mathrm{mm}^{2}$ active area INCA X-act silicon-drift detector (Oxford Instrument). For each sample, several areas were observed with the following power parameters: $\mathrm{EHT}=20 \mathrm{kV}$, $\mathrm{I}_{\text {Target }}=1.730 \mathrm{~A}$ and beam intensity of $300 \mathrm{pA}$. The experimental emission spectra of the regions of interest were acquired at the instrument-ideal working distance of $8.5 \mathrm{~mm}$ (gun-to-sample-surface). Both the SEM images and the emission spectra were acquired using back-scattered electrons (BSE) in order to, respectively, maximize the phase contrast and the interaction volume of the incident beam with the sample. 


\section{Results}

\subsection{Coefficient of Friction}

The evolution of the CoFs (coefficient[s] of friction) of the six pin/disc combinations is depicted in Figure 2, where a running-in period is seen before reaching steady state. In the running-in period, the contacting pin and disc surfaces grew more conformal, resulting in a gradual increase in CoFs. The steady state (about $3500 \mathrm{~s}$ to $7000 \mathrm{~s}$, in the current study) is more representative of real applications, thus, only the data in this period was considered for calculating the mean values and standard deviations from four repetitions of each pin/disc combination.

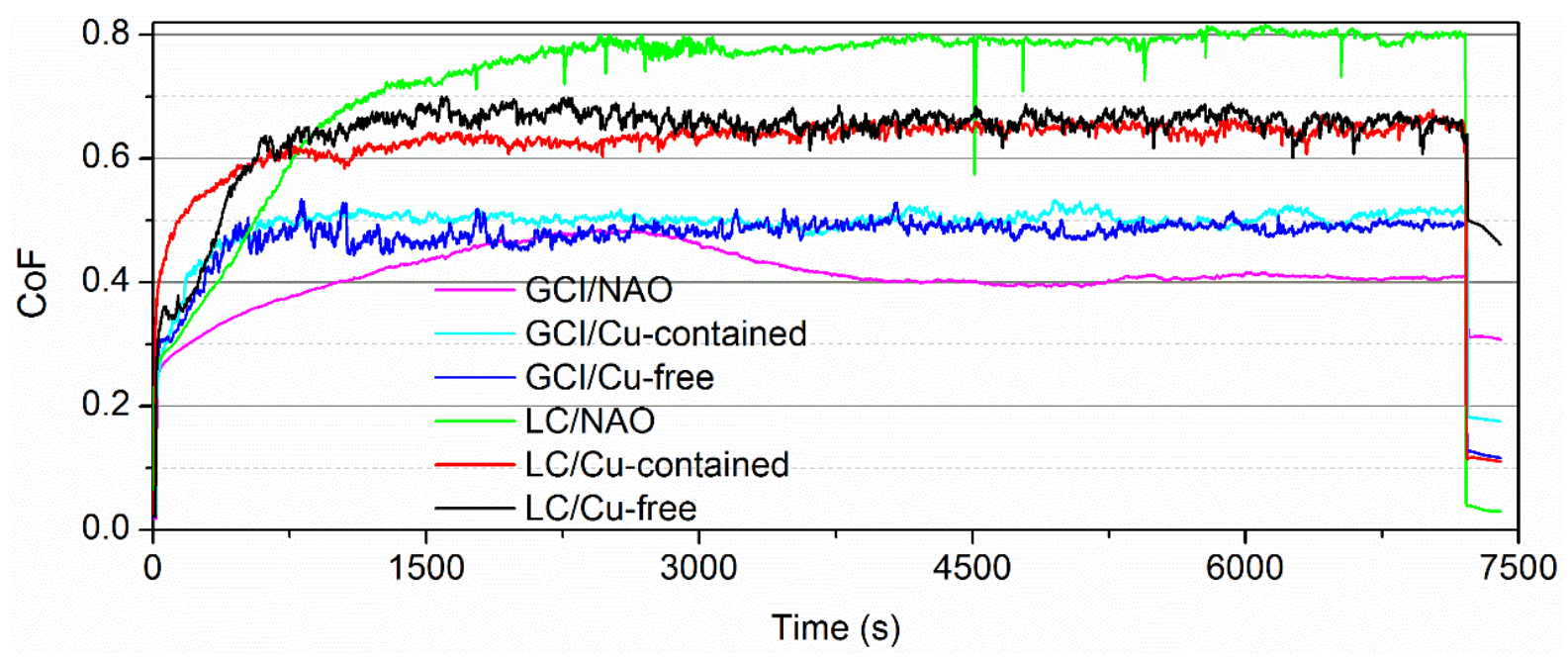

Figure 2. CoF time history from representative test runs of six pin/disc combinations.

\subsection{Particle Number Concentration}

The particle number concentration (PNC) of each material combination also shows a similar running-in period, followed by the steady state, as can be seen in Figure 3. The occurrence of the running-in and steady-state periods of the PNC time histories is attributed to the engagement process of the pin's and disc's surfaces in becoming conformal. Similarly to the CoF data, only the data from the steady state was used to consider the average PNC results and particle size distribution, in order to be more representative of real applications.

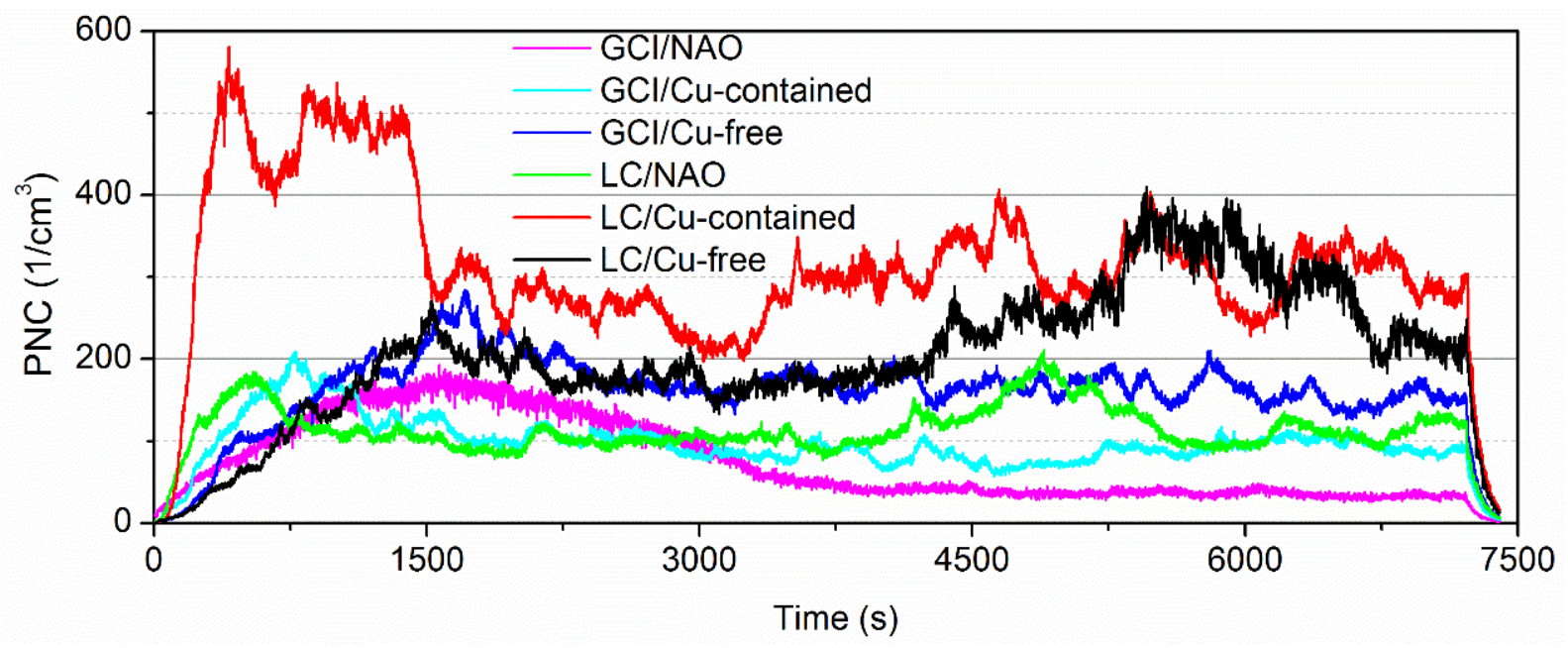

Figure 3. PNC time history from representative test runs of six pin/disc combinations. 


\subsection{Wear}

The mass loss of the tested pin and disc samples were measured by weighing them before and after each test with a Sartorius ${ }^{\circledR}$ (Göttingen, Germany) ME614S analytical balance (accuracy $0.1 \mathrm{mg}$ ). With the mass loss and density known, the wear volume of each sample could be determined and taken into the calculation of the specific wear rate with the following equation:

$$
k=\frac{\Delta m}{\rho \cdot s \cdot F_{N}}
$$

where $\Delta m$ is the mass loss of the sample, $\rho$ the density of the sample, $s$ the sliding distance $\left(14,400 \mathrm{~m}\right.$ for each test run in the current study) and $F_{N}$ the normal load applied on the pin/disc contact (shown in Table 3). The method enables the determination of the specific wear rates of both the pin and disc. This method is beneficial to real applications because the wear condition of disc brake systems is usually investigated by observing the wear volumes of the brake pad and brake rotor. The calculated mean value and stand deviation of the $\mathrm{CoF}$ and the specific wear rates of the pin and disc, as well as the PNC, are listed in Table 4.

Table 4. Mean value and standard deviation of the $\mathrm{CoF}, k_{\text {pin }}, k_{\text {disc }}$, and PNC for six material combinations.

\begin{tabular}{cccccc}
\hline Disc & Pin & CoF & $\boldsymbol{k}_{\text {pin }}\left(\mathbf{1 0}^{-\mathbf{1 4}} \mathbf{~ m}^{\mathbf{2}} \mathbf{N}\right)$ & $\boldsymbol{k}_{\text {disc }}\left(\mathbf{1 0}^{-\mathbf{1 4}} \mathbf{~ m}^{\mathbf{2}} / \mathbf{N}\right)$ & $\mathbf{P N C}\left(\mathbf{1} / \mathbf{c m}^{\mathbf{3}}\right)$ \\
\hline \multirow{2}{*}{ GCI } & NAO & $0.44 \pm 0.02$ & $0.98 \pm 0.11$ & $0.35 \pm 0.04$ & $59.7 \pm 28.6$ \\
& Cu-containing & $0.52 \pm 0.01$ & $3.54 \pm 0.13$ & $1.28 \pm 0.18$ & $132.8 \pm 55.8$ \\
& Cu-free & $0.53 \pm 0.03$ & $4.16 \pm 0.26$ & $1.43 \pm 0.17$ & $148.9 \pm 25.4$ \\
\hline \multirow{2}{*}{ LC } & NAO & $0.80 \pm 0.02$ & $4.38 \pm 0.61$ & $0.61 \pm 0.06$ & $157.2 \pm 22.8$ \\
& Cu-containing & $0.65 \pm 0.01$ & $5.74 \pm 0.42$ & $1.47 \pm 0.11$ & $303.2 \pm 53.1$ \\
& Cu-free & $0.63 \pm 0.04$ & $5.13 \pm 0.36$ & $1.45 \pm 0.17$ & $309.3 \pm 33.2$ \\
\hline
\end{tabular}

\subsection{Analysis of Worn Surfaces}

SEM observations and EDXS analyses were used to observe the pin and disc wear surfaces, and to identify the main components of the friction layers. The friction layer is made up of primary plateaus, composed by reinforcements of the friction material, and secondary plateaus that are made of wear debris from both the pin and disc [26]. The friction layer that formed during the PoD sliding test between the pin and disc determines the behaviour of the materials under study. Since the focus of this study is an NAO friction material, the $\mathrm{Cu}$-free material was considered representative of the low-metallic materials for comparison with the NAO formulation.

Figure 4 shows the top view of the worn $\mathrm{Cu}$-free pins (Figure $4 \mathrm{a}, \mathrm{b}$ ) that were tested against the GCI and LC discs (Figure 4c,d). On the friction material, primary plateaus made of iron fibres were visible, and secondary plateaus, formed from compacted wear fragments, are close to them. The secondary plateaus on the GCI/Cu-free pin were well compacted and wide (Figure $4 \mathrm{a}$ ), while those on the $\mathrm{LC} / \mathrm{Cu}$-free pin were not so wide and are mainly formed over the metal fibres (Figure $4 \mathrm{~b}$ ). On the disc-worn surfaces, the situation was different: the friction layer deposited on the GCI disc (Figure 4c) mainly accumulated inside the graphite zones, whilst an extensive amount of friction layer was spread on the LC discs along the whole sliding track (Figure $4 \mathrm{~d}$ ). The SEM observations were consistent with the calculated higher pin wear for the $\mathrm{LC} / \mathrm{Cu}$-free surfaces over their $\mathrm{GCI} / \mathrm{Cu}$-free counterparts (Table 4). Furthermore, it can be assumed that the less extensive secondary plateaus on the $\mathrm{LC} / \mathrm{Cu}$-free materials left the iron fibres more exposed and in contact with the disc, contributing to the increase in the CoF. 


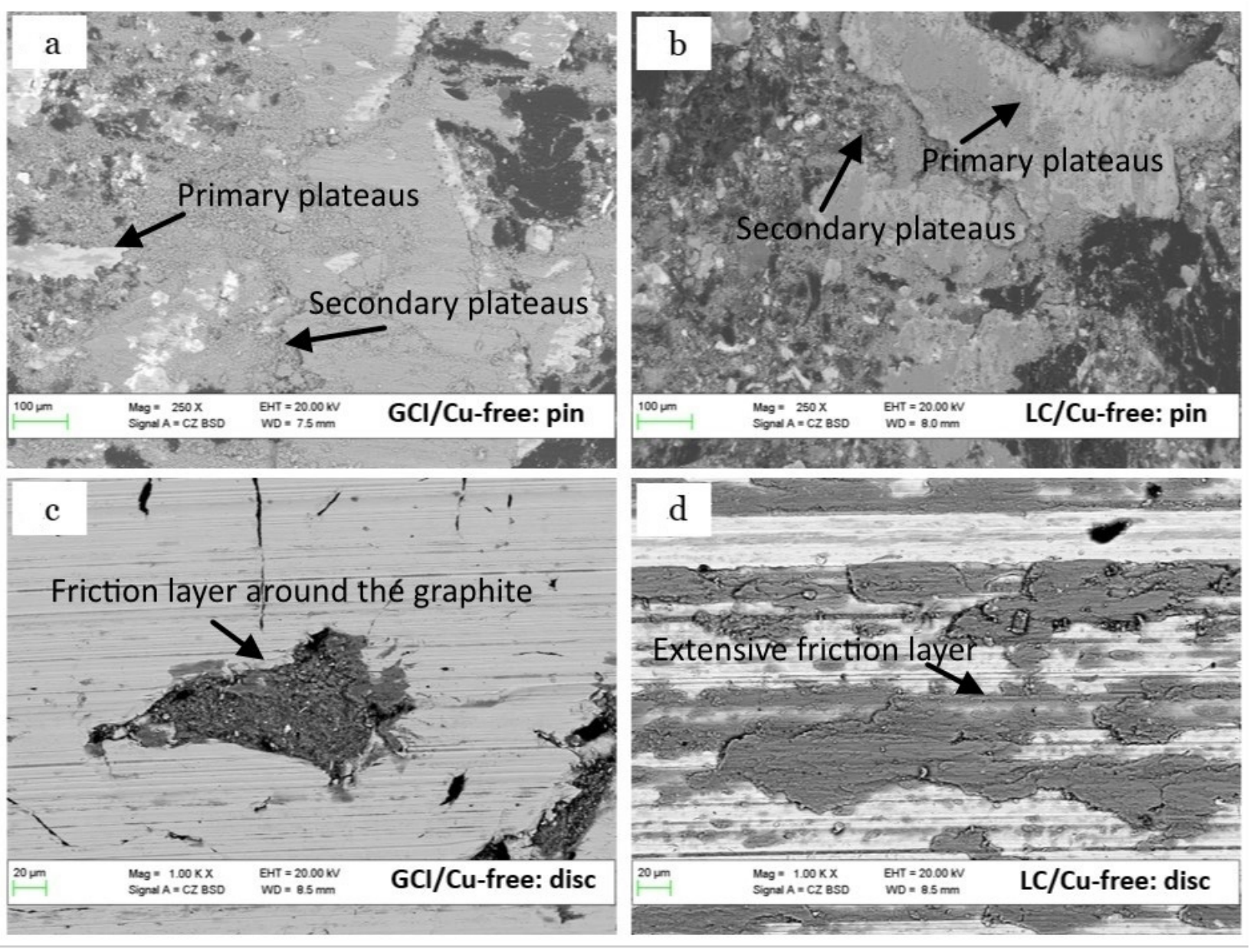

Figure 4. SEM micrographs of the planar sections of the worn pin surfaces of the Cu-free material (a,b) and the corresponding worn discs: GCI and LC (c,d).

Figure 5 shows the top view of the worn NAO pins (Figure $5 a, b$ ) tested against the GCI and LC discs (Figure 5c,d). NAO friction materials contain fewer metal fibres than low-metal materials, as can also be appreciated from the SEM observations. In the case of the GCI/NAO coupling, large areas of compacted wear fragments were observed on the surface of the pin, which formed extended secondary plateaus (Figure 5a). It is possible that the more yielding material on the underside allowed the wear fragments to compact without metal fibres to serve as primary plateaus. On the disc surface, there was an extensive and quite uniform distribution of the friction layer (the black phase in Figure 5c) along the sliding track. In the case of the LC/NAO materials, on the other hand, the wear fragments present on the pin formed less extensive but more evenly distributed compacted zones-also involving carbon constituents-that were not involved in the previous case. As in the case of cast iron, a homogeneous but less abundant distribution of friction layers was observed on the LC disc (the black phase is seen in Figure $5 d$, but less so than in Figure $5 c$ ).

Table 5 shows the EDXS analyses carried out on the secondary plateaus identified on the surface of the pins. Significant differences qwre observed between the two friction material formulations: low-metal $\mathrm{Cu}$-free and NAO. In the $\mathrm{Cu}$-free material, the friction layer consisted mainly of Fe, this constituent being present more on the surface that had slid against the GCI disc, as compared with the LC disc. Conversely, in NAO materials, the Fe content is much lower and is replaced by other elements, such as $\mathrm{Zr}$ and Ti. Of particular interest is the high $\mathrm{C}$ content in the friction layer of the LC/NAO material as compared with the others-this agrees with the SEM observations. It can therefore be assumed that the involvement of the carbonaceous constituents in the formation of the friction layer was 
responsible for the unique behaviour observed for this material: a high $\mathrm{CoF}$ and low wear and fewer particle emissions.
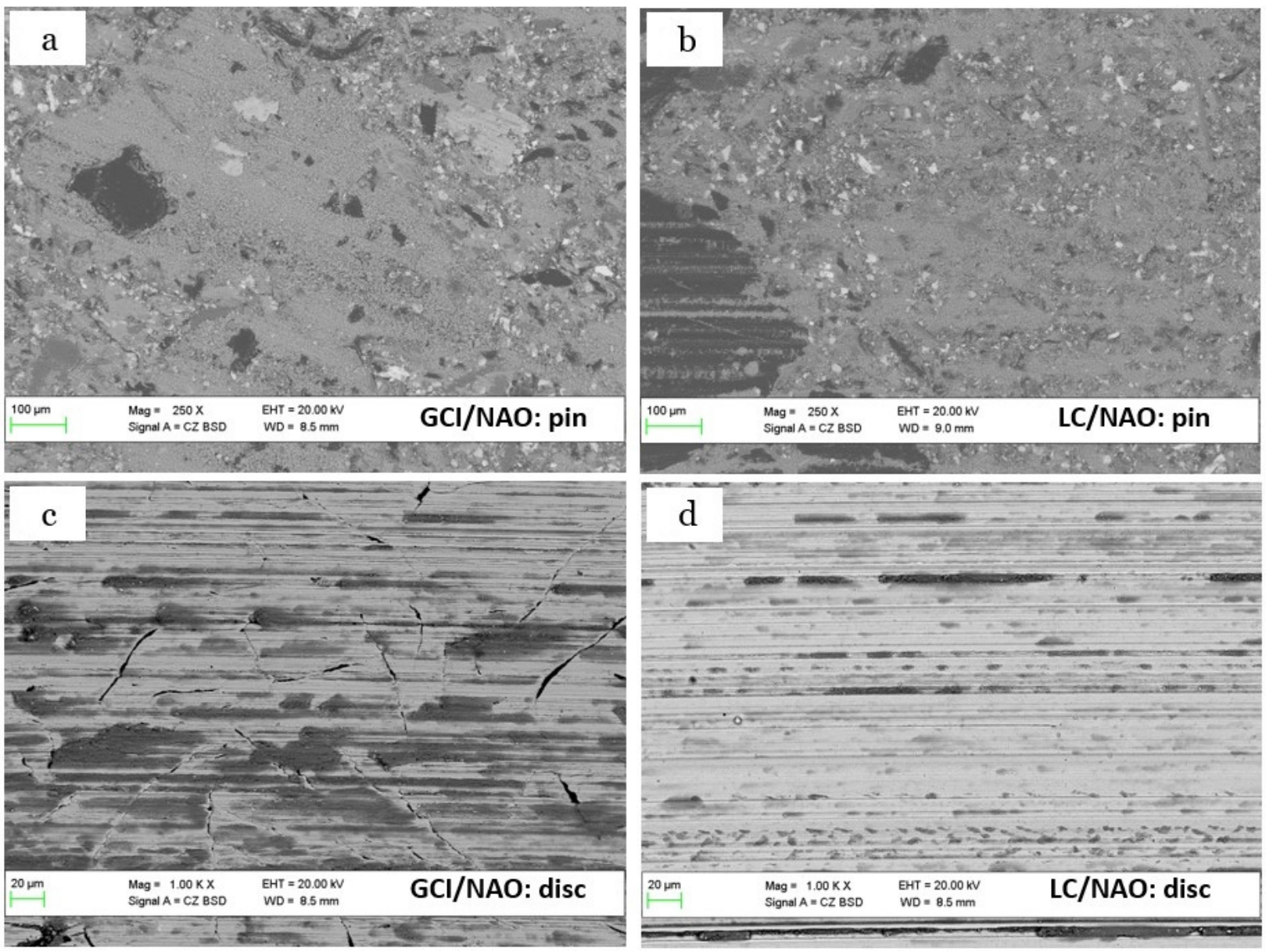

Figure 5. SEM micrographs of the planar sections of the worn pin surfaces of NAO material $(\mathbf{a}, \mathbf{b})$ and the related worn discs: GCI and LC (c,d).

Table 5. EDXS of the friction layers present on the pin surface.

\begin{tabular}{ccccc}
\hline Element [wt.\%] & GCI/Cu-Free & LC/Cu-Free & GCI/NAO & LC/NAO \\
\hline $\mathrm{C}$ & 8.95 & 7.24 & 7.94 & 16.06 \\
$\mathrm{O}$ & 28.12 & 28.23 & 38.24 & 37.13 \\
$\mathrm{Fe}$ & 43.07 & 39.29 & 17.89 & 17.66 \\
$\mathrm{Zr}$ & 0 & 0 & 15.35 & 9.05 \\
$\mathrm{Mg}$ & 1.37 & 1.16 & 4.00 & 3.09 \\
$\mathrm{Al}$ & 1.57 & 1.27 & 0.67 & 0.45 \\
$\mathrm{Si}$ & 1.21 & 1.41 & 2.74 & 1.98 \\
$\mathrm{~S}$ & 3.21 & 2.66 & 2.04 & 1.42 \\
$\mathrm{Ca}$ & 0.51 & 0.42 & 3.21 & 3.77 \\
$\mathrm{Cr}$ & 0.55 & 7.81 & 0 & 4.09 \\
$\mathrm{Ba}$ & 7.19 & 6.25 & 0 & 0 \\
$\mathrm{Ti}$ & 0 & 0 & 6.88 & 4.62 \\
$\mathrm{Zn}$ & 2.51 & 1.96 & 0 & 0 \\
$\mathrm{Sn}$ & 1.64 & 1.32 & 0.90 & 0 \\
Others & 0.14 & 0.98 & 0.14 & 0.68 \\
\hline
\end{tabular}

\section{Discussion}

It can be seen from Figure 2 and Table 4 that the NAO sample had the lowest CoF against the GCI disc and the highest against the LC disc, indicating its very distinguishable 
friction mechanisms on different disc surfaces. At the same time, the GCI/NAO pairing had the lowest specific wear rate of the pin and disc, as well as the lowest PNC among all material combinations. If only considering the tests on LC discs, the NAO samples also result in lower pin and disc wear rates and PNCs as compared with the low-metallic $\mathrm{Cu}$-containing and $\mathrm{Cu}$-free samples. In some previous studies, NAO brake material has also been observed to have lower wear and particle emission than low-metallic brake materials under both PoD tribometer and dynamometer testing [27-29]. The main reason is attributed to the less-aggressive wear process in NAO brake materials due to their better tribological compatibilities with Fe. This less-aggressive wear can also be identified in the SEM micrographs presented in Figures 4 and 5, where less-aggressive wear is noticeable for the discs run against the NAO pad material as compared to the semi-metallic $\mathrm{Cu}$-free one. Other studies have also demonstrated decreased wear rates and particle emission in laser-cladded coatings than in cast iron materials, but these coatings were all $\mathrm{Ni} / \mathrm{Co}$-based and reinforced with tungsten carbides [9-13], which is not the case in the current study.

Only one previous study on a laser-cladded Fe-based coating was found, in which the laser-cladded coating was tested against a low-metallic brake pad and presented twice the disc wear and particle concentration of a GCI disc [22], which agrees with the observations in the current study. However, the performance of NAO brake materials on laser-cladded brake rotors has not been investigated before; here, our study shows very encouraging results: although the NAO sample addressed the pin's wear rate equivalently to the lowmetallic $\mathrm{Cu}$-contained and $\mathrm{Cu}$-free samples (Table 4), it also produced half the disc wear and PNC of the low-metallic brake materials. Further, the disc wear rate from the LC/NAO pairing was even lower than the $\mathrm{Cu}$-containing/GCI and $\mathrm{Cu}$-free/GCI pairings, apart from their equivalent PNCs, demonstrating the NAO material's great potential as a proper counter proposal to efforts toward LC Fe-based coatings on GCI substrates.

The NAO samples also demonstrated advantages in terms of particle size distribution, as presented in Figure 6. The friction pairings, including the $\mathrm{Cu}$-containing and $\mathrm{Cu}$-free brake-pad materials, exhibited a clear dual-modal distribution with two modes, i.e., one at $0.5 \mu \mathrm{m}$ and the other at $2 \mu \mathrm{m}$. The GCI/NAO pairing and LC/NAO pairing, however, seemingly showed a unimodal distribution with a unique mode at $0.5 \mu \mathrm{m}$, whilst the peak around $2 \mu \mathrm{m}$, seen in the prior pairings, was, here, largely flattened.

Another analysis was conducted with the output of the raw number counts of each channel from the OPS. Of note, the OPS measures particle sizes ranging from 0.3-10 $\mu \mathrm{m}$ over 16 size channels, of which 5 channels are below $1 \mu \mathrm{m}$, i.e., fine particles [30]. The particle number fraction of fine particles is calculated from the raw number counts, following the equation below, the results from which are shown in Figure 7:

$$
\text { Fine particle fraction }=\frac{\sum_{i=1}^{5} N_{i}}{\sum_{i=1}^{16} N_{i}}
$$

where $N_{i}$ is the raw number counts from size channel $i$.

It is widely accepted that the toxicity of airborne particles is strongly correlated with particle size and, usually, the smaller the particles, the more hazardous they are [31]. It can be seen that more than $80 \%$ of the particles generated from the GCI/NAO pairing were fine particles, which is unwelcomed. On the contrary, the LC/NAO pairing demonstrated the lowest fine particle fraction, of around $70 \%$, followed by the $\mathrm{GCI} / \mathrm{Cu}$-containing and $\mathrm{GCI} / \mathrm{Cu}$-free pairings. This indicates that the NAO pins tended to generate a smaller fraction of harmful fine particles in LC coatings than low-metallic $\mathrm{Cu}$-containing and $\mathrm{Cu}$ free pins. Connected to the lower wear rate and PNC of the NAO brake material, this create much potential for coping with the challenges of LC coatings on GCI substrates $[13,22]$. 

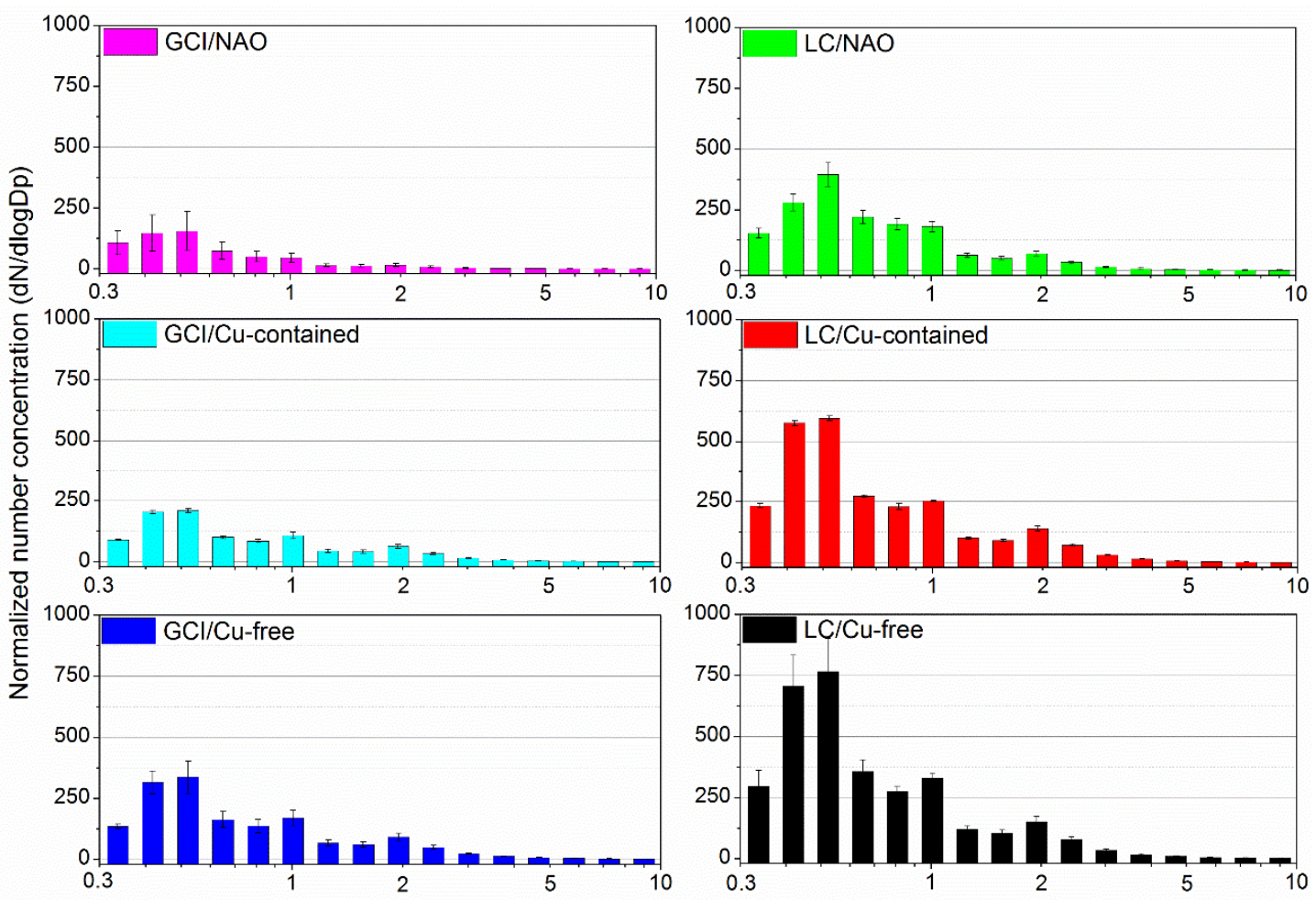

Particle diameter $(\mu \mathrm{m})$

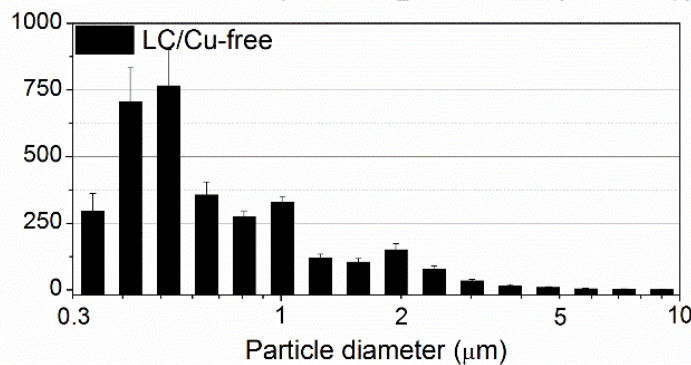

Figure 6. Normalized particle number concentration of the six pin/disc combinations in a steady state.

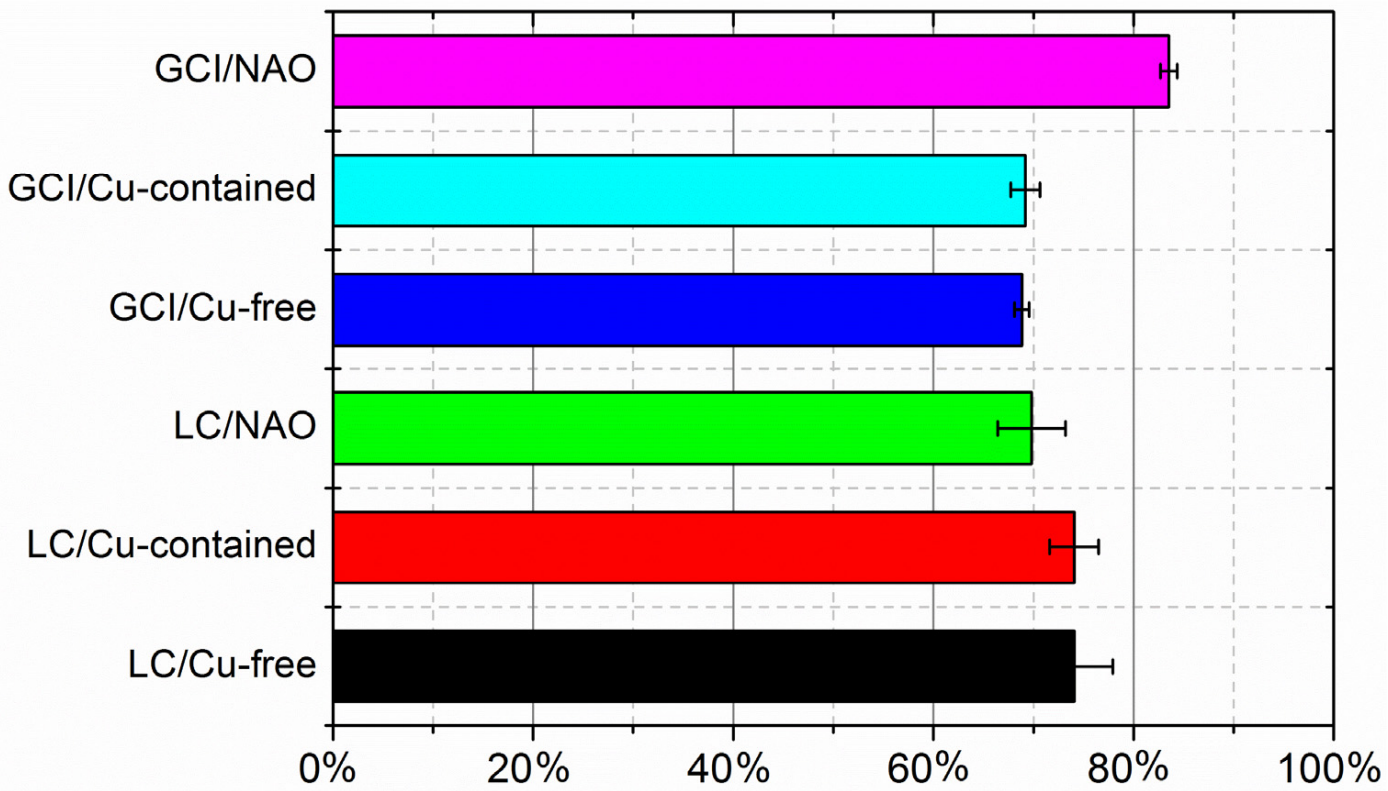

Fraction of fine particles $(<1 \mu \mathrm{m})$

Figure 7. Raw number count fraction of fine particles $(0.3-1 \mu \mathrm{m})$ of the six material combinations.

\section{Conclusions}

A pin-on-disc tribometer study was conducted to evaluate the coefficient of friction $(\mathrm{CoF})$, specific wear rate and particle number concentration (PNC) of a non-asbestos organic (NAO) and two low-metallic (one $\mathrm{Cu}$-contained and one $\mathrm{Cu}$-free) brake-pad materials tested against a traditional grey cast iron (GCI) and a laser-cladded Fe-based brake rotor. The major conclusions drawn are as follows: 
The NAO/LC friction pairing showed equivalent PNC and reduced disc wear as compared with traditional low-metallic/GCI friction pairings, which is about $50 \%$ lower than the low-metallic/LC friction pairings, demonstrating the suitability of NAO brake pad materials for LC brake rotors.

The NAO/LC friction pairing presented a much higher CoF than the other friction pairings, which is likely to be attributed to the higher content of carbonaceous constituents in the brake-pad material.

The worn surfaces of the low-metallic/GCI, NAO/GCI and NAO/LC friction pairings displayed very compacted friction layers, composed of primary and secondary plateaus, whilst the low-metallic/LC worn surface seemed less compacted, resulting in a doubled PNC.

The examined NAO brake-pad material exhibited a unimodal particle size distribution, with a unique mode at $0.5 \mu \mathrm{m}$, against both the GCI and LC brake rotors, whilst the lowmetallic brake-pad materials showed a dual modal distribution with two modes, at $0.5 \mu \mathrm{m}$ and $2 \mu \mathrm{m}$.

The NAO/LC friction pairing had a lower fraction of fine particles (sub-1 $\mu \mathrm{m}$ ) than the two low-metallic/LC friction pairings.

Future work is encouraged to focus on the nanoparticle (sub-100 nm) emissions from laser-cladded brake rotors.

Author Contributions: Conceptualization, J.W. and U.O.; tribological test, Y.L.; materials characterization, M.L. and A.M.; data analysis, Y.L., M.L., J.W. and U.O.; writing-original draft preparation, Y.L., M.L., A.M., J.W. and U.O.; writing-review and editing, Y.L.; supervision, J.W. and U.O.; project administration, Y.L. and U.O.; funding acquisition, Y.L. and U.O. All authors have read and agreed to the published version of the manuscript.

Funding: This research was funded by [FORMAS: Swedish Research Council for Sustainable Development] grant number [2020-02302] (Nescup project). The research also received funding from [European Union's Horizon 2020 Research and Innovation Programme] grant number [954377] (nPETS project).

Data Availability Statement: Data sharing is not applicable.

Conflicts of Interest: The authors declare no conflict of interest.

$\begin{array}{ll}\text { Abbreviations } \\ \text { LC } & \text { laser cladding/laser-cladded } \\ \text { NAO } & \text { non-asbestos organic } \\ \text { PoD } & \text { pin-on-disc tribometer } \\ \text { GCI } & \text { gray cast iron } \\ \text { HVOF } & \text { high-velocity oxy-fuel } \\ \text { CoF } & \text { coefficient of friction } \\ \text { HEPA } & \text { high efficiency particulate absorbing } \\ \text { PNC } & \text { particle number concentration } \\ \text { SEM } & \text { scanning electron microscopy } \\ \text { EDXS } & \text { energy dispersive X-ray spectroscopy } \\ \text { XRF } & \text { X-ray fluorescence spectrometer }\end{array}$

\section{References}

1. Aranke, O.; Algenaid, W.; Awe, S.; Joshi, S. Coatings for Automotive Gray Cast Iron Brake Discs: A Review. Coatings 2019, 9, 552. [CrossRef]

2. Adebisi, A.; Maleque, M.; Rahman, M.M. Metal matrix composite brake rotor: Historical development and product life cycle analysis. Int. J. Automot. Mech. Eng. 2011, 4, 471-480. [CrossRef]

3. Renz, R.; Seifert, G.; Krenkel, W. Integration of CMC brake disks in automotive brake systems. Int. J. Appl. Ceram. Technol. 2012, 9, 712-724. [CrossRef]

4. Federici, M.; Menapace, C.; Moscatelli, A.; Gialanella, S.; Straffelini, G. Effect of roughness on the wear behavior of HVOF coatings dry sliding against a friction material. Wear 2016, 368-369, 326-334. [CrossRef] 
5. Federici, M.; Menapace, C.; Moscatelli, A.; Gialanella, S.; Straffelini, G. Pin-on-disc study of a friction material dry sliding against HVOF coated discs at room temperature and $300{ }^{\circ} \mathrm{C}$. Tribol. Int. 2017, 115, 89-99. [CrossRef]

6. Wahlström, J.; Lyu, Y.; Matjeka, V.; Söderberg, A. A pin-on-disc tribometer study of disc brake contact pairs with respect to wear and airborne particle emissions. Wear 2017, 384-385, 124-130. [CrossRef]

7. Federici, M.; Menapace, C.; Mancini, A.; Straffelini, G.; Gialanella, S. Pin-on-disc study of dry sliding behavior of Co-free HVOF-coated disc tested against different friction materials. Friction 2021, 9, 1242-1258. [CrossRef]

8. Sobolev, V.V.; Guilemany, J.M.; Nutting, J.; Joshi, S. High Velocity Oxy-Fuel Spraying: Theory, Structure-Property Relationships and Applications; Maney: London, UK, 2004.

9. Van Acker, K.; Vanhoyweghen, D.; Persoons, R.; Vangrunderbeek, J. Influence of tungsten carbide particle size and distribution on the wear resistance of laser clad WC/Ni coatings. Wear 2005, 258, 194-202. [CrossRef]

10. Ocelík, V.; De Oliveira, U.; De Boer, M.; De Hosson, J.T.M. Thick Co-based coating on cast iron by side laser cladding: Analysis of processing conditions and coating properties. Surf. Coat. Technol. 2007, 201, 5875-5883. [CrossRef]

11. Fernández, E.; Cadenas, M.; González, R.; Navas, C.; Fernández, R.; De Damborenea, J. Wear behaviour of laser clad NiCrBSi coating. Wear 2005, 259, 870-875. [CrossRef]

12. Cadenas, M.; Vijande, R.; Montes, H.; Sierra, J. Wear behaviour of laser cladded and plasma sprayed WC Co coatings. Wear 1997, 212, 244-253. [CrossRef]

13. Dizdar, S.; Lyu, Y.; Lampa, C.; Olofsson, U. Grey Cast Iron Brake Discs Laser Cladded with Nickel-Tungsten Carbide-Friction, Wear and Airborne Wear Particle Emission. Atmosphere 2020, 11, 621. [CrossRef]

14. Leyssens, L.; Vinck, B.; Van Der Straeten, C.; Wuyts, F.; Maes, L. Cobalt toxicity in humans-A review of the potential sources and systemic health effects. Toxicology 2017, 387, 43-56. [CrossRef]

15. Denkhaus, E.; Salnikow, K. Nickel essentiality, toxicity, and carcinogenicity. Crit. Rev. Oncol./Hematol. 2002, 42, 35-56. [CrossRef]

16. Bastian, S.; Busch, W.; Kühnel, D.; Springer, A.; Meißner, T.; Holke, R.; Scholz, S.; Iwe, M.; Pompe, W.; Gelinsky, M.; et al. Toxicity of Tungsten Carbide and Cobalt-Doped Tungsten Carbide Nanoparticles in Mammalian Cells in Vitro. Environ. Heal. Perspect. 2009, 117, 530-536. [CrossRef] [PubMed]

17. Crundwell, F.; Moats, M.; Ramachandran, V.; Robinson, T.; Davenport, W.G. Extractive Metallurgy of Nickel, Cobalt and Platinum Group Metals; Elsevier: Amsterdam, The Netherlands, 2011.

18. Bolelli, G.; Börner, T.; Milanti, A.; Lusvarghi, L.; Laurila, J.; Koivuluoto, H.; Niemi, K.; Vuoristo, P. Tribological behavior of HVOF-and HVAF-sprayed composite coatings based on Fe-Alloy+ WC-12\% Co. Surf. Coat. Technol. 2014, 248, 104-112. [CrossRef]

19. Bolelli, G.; Bursi, M.; Lusvarghi, L.; Manfredini, T.; Matikainen, V.; Rigon, R.; Sassatelli, P.; Vuoristo, P. Tribology of FeVCrC coatings deposited by HVOF and HVAF thermal spray processes. Wear 2018, 394, 113-133. [CrossRef]

20. Milanti, A.; Matikainen, V.; Bolelli, G.; Koivuluoto, H.; Lusvarghi, L.; Vuoristo, P. Microstructure and sliding wear behavior of Fe-based coatings manufactured with HVOF and HVAF thermal spray processes. J. Therm. Spray Technol. 2016, 25, $1040-1055$. [CrossRef]

21. Bolelli, G.; Börner, T.; Bozza, F.; Cannillo, V.; Cirillo, G.; Lusvarghi, L. Cermet coatings with Fe-based matrix as alternative to WC-CoCr: Mechanical and tribological behaviours. Surf. Coat. Technol. 2012, 206, 4079-4094. [CrossRef]

22. Olofsson, U.; Lyu, Y.; Åström, A.H.; Wahlström, J.; Dizdar, S.; Nogueira, A.P.G.; Gialanella, S. Laser Cladding Treatment for Refurbishing Disc Brake Rotors: Environmental and Tribological Analysis. Tribol. Lett. 2021, 69, 57. [CrossRef]

23. Peterson, M.B.; Winer, W.O. Wear Control Handbook; ASME: New York, NY, USA, 1980.

24. Liu, Y.; Daum, P.H. The effect of refractive index on size distributions and light scattering coefficients derived from optical particle counters. J. Aerosol Sci. 2000, 31, 945-957. [CrossRef]

25. Lyu, Y.; Leonardi, M.; Wahlström, J.; Gialanella, S.; Olofsson, U. Friction, wear and airborne particle emission from Cu-free brake materials. Tribol. Int. 2020, 141, 105959. [CrossRef]

26. Eriksson, M.; Bergman, F.; Jacobson, S. On the nature of tribological contact in automotive brakes. Wear 2002, 252, 26-36. [CrossRef]

27. Wahlström, J.; Söderberg, A.; Olander, L.; Jansson, A.; Olofsson, U. A pin-on-disc simulation of airborne wear particles from disc brakes. Wear 2010, 268, 763-769. [CrossRef]

28. Perricone, G.; Matějka, V.; Alemani, M.; Valota, G.; Bonfanti, A.; Ciotti, A.; Olofsson, U.; Söderberg, A.; Wahlström, J.; Nosko, O.; et al. A concept for reducing PM 10 emissions for car brakes by 50\%. Wear 2018, 396-397, 135-145. [CrossRef]

29. Sanders, P.G.; Xu, N.; Dalka, T.M.; Maricq, M.M. Airborne Brake Wear Debris: Size Distributions, Composition, and a Comparison of Dynamometer and Vehicle Tests. Environ. Sci. Technol. 2003, 37, 4060-4069. [CrossRef]

30. Lin, C.-C.; Chen, S.-J.; Huang, K.-L.; Hwang, W.-I.; Chang-Chien, G.-P.; Lin, W.-Y. Characteristics of metals in nano/ultrafine/fine/coarse particles collected beside a heavily trafficked road. Environ. Sci. Technol. 2005, 39, 8113-8122. [CrossRef] [PubMed]

31. Becker, S.; Soukup, J.M.; Sioutas, C.; Cassee, F.R. Response of human alveolar macrophages to ultrafine, fine, and coarse urban air pollution particles. Exp. Lung Res. 2003, 29, 29-44. [CrossRef] 